\title{
Предмет и цели договора о Шпицбергене (Свальбарде) с точки зрения международного морского права
}

\section{Рольф Эйнар Фифе*}

\section{Введение}

Договор о Шпицбергене (Свальбарде) был подписан 9 февраля 1920 г. в Париже, в выдержанном в стиле Второй империи «Салоне де л'орлож» в здании французского министерства иностранных дел на Кэ д' Орсэ. Церемония состоялась на фоне политического кризиса, возникшего на мирной конференции, проходившей в Париже после окончания первой мировой войны: ее главной целью было установление мира и экономическое восстановление разоренной войной Европы. Однако оптимизм постепенно уступил место разочарованию. Так, в сентябре 1919 г. французский посол в Великобритании Поль Камбон отмечал в письме к сыну: «Куда ни повернись, искры уже летят. Воистину, в истории было немного мирных конференций, столь же успешно разжигавших аппетиты и создававших новые источники конфликтов»!. Тем не менее, в отличие от других документов, принятых на конференции, Договор по Шпицбергену выдержал проверку временем, обеспечивая мирное, эффективное и справедливое управление этим арктическим архипелагом. Поэтому его можно отнести к успешным результатам Парижской конференции.

И все же истолкование географических рамок Договора, а точнее вопрос о его применимости за пределами территориальных вод, вызывает разногласия. В данной статье, пусть и в сжатой форме, рассматривается ряд положений, связанных с этой проблемой. В ней дается краткий обзор практической деятельности Норвегии, в частности по сохранению и ответственной эксплуатации ресурсов в прилегающих к архипелагу водах.

\footnotetext{
- Рольф Эйнар Фифе - директор юридического департамента Министерства иностранных дел Норвегии. Данная статья не является отражением официальной позиции правительства Норвегии. Она представляет собой слегка измененный вариант статьи, написанной по-французски, "L'objet et le but du traité du Spitsberg (Svalbard) et le droit de la mer" и опубликованной в книге La mer et son droit. Mélanges offerts $\dot{r}$ Laurent Luccini et Jean-Pierre Quéneudec, Paris, Editions A. Pedone, 2003. P. 239-262.

' Paul Cambon, Correspondence, Vol. III, Paris, Grasset, 1946. P. 358.
} 


\section{Географический контекст}

Арктический архипелаг Шпицберген (Свальбард) расположен на полпути между континентальной территорией Норвегии и Северным полюсом: его омывают Северный Ледовитый океан, а также Норвежское, Гренландское и Баренцево моря. Он состоит из островов, расположенных между 10 и 35 градусами восточной долготы и 74 и 81 градусами северной широты. Общая площадь островов составляет около 62700 кв. км, т.е. примерно (grosso modo) равна территории Бельгии и Нидерландов вместе взятых. Около 54\% поверхности архипелага покрыто толстым ледяным панцирем ${ }^{2}$. Все поселения, существующие на архипелаге, в том числе и его административный центр, город Лонгьир, располагаются на крупнейшем острове - Шпицбергене ${ }^{3}$.

Экономическая деятельность на островах в основном связана с имеющимися там месторождениями угля - его добычей занимаются юрвежская фирма и российское предприятие. Кроме того, Свальбард стал одним из излюбленных мест для научных исследований и туризма. Иностранцы пользуются правом свободного доступа и въезда на архипелаг, а также имеют право, при условии соблюдения местных законов и правил, заниматься различными видами деятельности на основе полного равенства. Кроме того, доступ на острова, учитывая, что они расположены на Крайнем Севере, можно назвать чрезвычайно легким благодаря теплым морским течениям и открытому в 1975 г. современному аэропорту. Поэтому норвежское правительство проявляет особую заботу о сохранении уникальной и уязвимой природной среды архипелага: эта цель была четко обозначена еше в Договоре $1920 r^{4}{ }^{4}$ Первые меры по защите окружающей среды были приняты в 1970х гг., и, несмотря на протесты со стороны Советского Союза, они соблюдаются всеми правообладателями. Учитывая тематику данной статьи, нельзя не упомянуть и о значении прибрежных вод Свальбарда, чья экосистема обеспечивает поголовье трески, обитающей в Северной Атлантике, жизненно необходимыми пишевыми ресурсами.

\footnotetext{
${ }^{2}$ Доклад № 9 о «Свальбарде» (1999-2000 гт.), представленный норвежскому парламенту (Стортингу). С. 8.

${ }^{3} \mathrm{C} 1925$ г. название «Шпицберген» (слово голландского происхождения, означающее «островерхие горы») ислользуется в Норвегии для обозначения главного острова, а весь архилелаг называется «Свальбард» (с древненорвежского - «холодные берега»).

${ }^{4}$ См.: Ст. 2, параграф 2.
} 


\section{Краткий исторический очерк о контексте подготовки и подписания Договора}

В 1910, 1912 и 1914 гг. в Кристиании ${ }^{5}$ по инициативе Норвегии состоялись конференции, призванные решить вопрос о статусе островов. В то время архипелаг считался «ничейной землей» (terra nullius), и сразу несколько государств проявляли к нему интерес с экономической и научной точки зрения. Эти дискуссии, связанные, в частности, с неудачным предложением о совместном норвежско-шведско-российском управлении островами, были прерваны из-за войны 1914-1918 гг.

Война во многих отношениях существенно изменила ситуацию. Хотя в годы войны Норвегия сохраняла нейтралитет, она понесла самые болъшие жертвы среди моряков гражданского флота. Благодаря географическому положению и наличию большого торгового флота, Норвегия оказала существенную помощь Антанте, являясь по сути ее «нейтральным союзником» ${ }^{7}$. Норвежские суда сыграли важнейшую роль в морских перевозках в зоне между российским портом в Архангельске и британскими портами. Особое значение в этой связи имели поставки нитратов норвежской компанией «Гидро» для французских военных заводов. Норвежцы были чуть ли не единственными, кто, невзирая на риск быть торпедированными, отваживался плавать по морям в годы войны ${ }^{8}$. Около 2000 норвежских моряков погибло, а 900 судов, составлявших $49 \%$ обшего тоннажа торгового флота страны, было потоплено 9

Эти обстоятельства стали главной причиной того, что в 1919 г. несколько держав были готовы включить шпицбергенский вопрос в повестку дня мирной конференции - хотя сам архипелаг военные действия не затронули - и признать суверенитет Норвегии над островами. В Парижской конференции, проходившей с 18 января по 28 июня, участвовали 27 государств; в ходе ее работы было создано 58 комиссий, в том числе и комиссия по Шпицбергену. На конференции отсут-

\footnotetext{
${ }^{5}$ Название г. Осло, употреблявшееся до 1924 г.

${ }^{6}$ Roald Berg, Norge pe egen hand 1905-1920, Vol. II (Norsk utenrikspolitikks historie), Oslo, Universitetsforlaget, 1995. P. 169, 171-172.

7 Это определение принадлежит Улаву Ристе. См. его книгу: Olav Riste, The Neutral Ally: Norway's Relations with Belligerent Powers in the First World War. Oslo, Universitetsforlaget, 1965.

${ }^{8}$ Pierre Renouvin, La crise européenne et la Premičre Guerre Mondiale, 3-rd ed., Paris, Presses Universitaires de France (PUF), 1948. P. 460.

${ }^{9}$ Berge Furre, Norsk Historie 1905-1990, Oslo, Det norske samlaget, 1992. P. 57.
} 
ствовали Германия и Советская Россия, которую западные страны на тот момент еше не признали. Тем не менее суверенитет Норвегии над архипелагом, судя по всему, устраивал все заинтересованные стороны: это позволяло обеспечить стратегическое равновесие и избежать возникновения новых источников напряженности между великими державами.

Норвегия представила соответствующий доклад Высшему совету Конференции по подготовке мирных договоров ${ }^{10} 10$ апреля 1919 г. После упоминания о переговорах, имевших место до войны, в докладе приводились следующие аргументы:

«К сегодняшнему моменту опыт ряда переговоров и работа Конференции 1914 г., судя по всему, в полной мере продемонстрировали, что на пути создания международной администрации на архипелаге Шпицберген и острове Медвежий, основанной на идее «ничейной земли» (terra nullius), имеются непреодолимые трудности, и единственным удовлетворительным и окончательным решением является возвращение архипелага Норвегии.

Это решение ни в коей мере не исключает договоренности, чтобы лица, ныне занимающие участки на архипелаге, получили возможность предъявить иски, связанные с их правами собственности, для рассмотрения международным трибуналом. Аналогичным образом норвежское правительство не станет возражать против включения параграфа относительно будущего контроля над шахтами Шпицбергена в соглашение о возвращении островов Норвегии.

Норвежское правительство убеждено, что, представляя данный вопрос, столь долгое время вызывавший споры, для обсуждения на Конференции, оно действует в интересах мира, и выражает надежду, что все державы согласятся без оговорок вернуть этот архипелаг Норвегии - единственной стране, когда-либо имевшей на него суверенные права»" ${ }^{11}$.

7 июля 1919 г. Совет создал комиссию по Шпицбергену. Та попросила Норвегию подготовить проект договора. Глава норвежской делегации Ведель-Ярлсберг описывает эти события следующим образом

\footnotetext{
${ }^{10} \mathrm{~B}$ состав Совета входили Соединенные Штаты Америки, Франция, Италия и Великобритания.

"Conférence de la Paix (1919-1920), Recuel des Actes de la Conférence, Commission du Spitsberg, Partie VII, Paris, 1924 (ärëli - Commission du Spitsberg). P. 116-119. Английский перевод с французского оригинала в книге: David Hunter MILLER, My Diary at the Conference of Paris, с документами, 1926, т. XVII, Бюллетень, С. 483.
} 
(приходится констатировать, что его рассказ отличается скорее краткостью, нежели скромностью):

«Весной и летом 1919 г. мне пришлось предпринять значительные усилия, чтобы привлечь внимание политических лидеров и пробудить у них интерес к нашим требованиям. Я поддерживал постоянные контакты с Францией, Англией и Америкой. Мирной конференции приходилось рассматривать такое количество проблем, что попытка включить в повестку дня вопросы, не занимавшие ни одно из этих государств, была делом поистине непростым. В конечном итоге, только благодаря личному контакту с Клемансо мне удалось побудить его специально и весьма энергично вмешаться в ход дела, и таким образом я сумел в самый последний момент добиться включения этих вопросов в повестку дня. Не мешкая ни минуты, я, вместе с юрисконсультом министерства иностранных дел Франции г-ном Фромажо составил проект международного договора о передаче Свальбарда Норвегии. Была создана комиссия, куда вошли представители заинтересованных держав. В конце сентября 1919 г. проект договора, который подготовили мы с Фромажо, был принят практически без поправок»'2.

На самом деле Ведель-Ярлсберг попросил бывшего министра юстиции Норвегии Фредрика Станга ${ }^{13}$ и юрисконсульта министерства иностранных дел Франции Анри Фромажо ${ }^{14}$ помочь в разработке про-

${ }^{12} \mathrm{~F}$. Wedel Jarlsberg, Reisen gjennom livet, Oslo, 1932. Р. 373 (автобиографические мемуары, написанные по-норвежски). Фредрик (Фриц) Ведель-Ярлсберг (1855-1942) был норвежским посланником в Париже и представлял Норвегию на мирной конференции. Он сыграл решающую роль в успешном завершении переговоров по Шпицбергену.

${ }^{13}$ Фредрик Станг (1867-1941) - профессор юридических наук, министр юстиции (19121913), председатель комиссии по Шпицбергену, учрежденной норвежской горнодобывающей компанией Store Norske Spitsbergen Kulkompani, ректор университета Осло (1921-1927). С 1922 по 1941 г. занимал пост председателя комитета по присуждению Нобелевской премии мира.

${ }^{14}$ Анри Фромажо (р. 1864) - главный юрист министерства иностранных дел Франции, в качестве судьи, доверенного лица или советника принимал участие в международных арбитражных судебных процессах и деятельности ряда комиссий по расследованию. Президент Англо-американского арбитражного суда по финансовым искам (1913-1922). Принимал участие в англо-французских переговорах в Лондоне в феврале 1915 г., связанных с подготовкой ответа на заявление германского Адмиралтейства о начале подводной войны, оказавшее значительное влияние на политический курс союзников в отношении соседних нейтральных государств, в том числе, и Норвегии. Был членом Центрального проектного комитета по подготовке Версальского договора, французским представителем в Лиге Наций, а в 1929 г. сменил Судью Андре Вейсса в Международном суде (переизбран на этот пост в 1930 г.). 
екта договора. Проект был внесен на рассмотрение комиссии 21 июля ${ }^{15}$; его представляли норвежский ученый-правовед Арнольд Рэстад ${ }^{16}$ и французский географ Шарль Рабо ${ }^{17} .5$ сентября, после единодушного одобрения проекта всеми заинтересованными державами, комиссия представила Высшему совету доклад, к которому прилагался проект договора. В докладе подчеркивалась необходимость решить этот вопрос раз и навсегда и формулировался следующий вывод:

«В настоящее время архипелаг является «ничейной землей», и все считают необходимым покончить с таким положением дел, определив его статус.

В этих целях возможны два решения: первое из них, предложенное различными державами и некоторыми членами Комиссии, заключается в предоставлении Норвегии мандата Лиги Наций. Второе решение, о котором просит Норвегия, заключается в передаче этой державе суверенитета над архипелагом при условии определенных гарантий в интересах других государств.

Учитывая большую заинтересованность Норвегии в Шпицбергене, ее близость к архипелагу и преимуцества, связанные с окончательнымм решением вопроса, Комиссия единодушно поддержала вторую процедуру, которая не вызывает никаких возражений у всех наиболее заинтересованных держав.

[...] При передаче Норвегии суверенитета над Шпицбергеном было необходимо, в целях защиты интересов других Договаривающихся Сторон, оговорить способ окончательного определения уже приобретенных на архипелаге прав, а затем и способ будущего урегулирова-

${ }^{15}$ Berg. Op. cit. P. 283-284.

${ }^{16}$ Арнольд Рэстад (1878-1945) зашитил докторскую диссертацию по проблемам морского права. На ее основе он опубликовал на французском языке книгу "La Mer Territoriale", удостоенную в 1913 г. премии Французского института. В журнале "La Géographie", 1912, Vol. 35. P. 337-354, (с 1900 по 1939 г. он назывался "Bulletin de la Société de Géographie de Paris") он опубликовал статью "Le Spitsberg dans l'histoire diplomatique"(«Шпицберген в истории дипломатии»). С июня 1921 г. по май 1922 г. он занимал пост министра иностранных дел Норвегии и ее представителя в Лиге Наций. Как и Фромажо, он в 1929 г. входил в состав Комитета юристов, образованного для внесения поправок в Статут Международного суда.

17 Шарль Рабо (1856-1944) - гляциолог, побывал на Шпицбергене в 1882 и 1892 гг. Занимал пост председателя Международной комиссии по ледникам и секретаря Парижского географического общества. Перевел на французский язык труды норвежских полярных исследователей Нансена и Свердрупа. Автор книг "Aux fjords de Norvčge et aux foręts de Sučde"(1898) и "Au Cap Nord" (1898). 
ния и осуществления вновь приобретаемых прав [...]. Поскольку все вопросы, связанные с правами, приобретенными до заключения настоящего Договора, были, таким образом, урегулированы, Комиссия сочла, что в отношении вновь приобретаемых прав и их осуществления должен применятся принцип полного равенства граждан всех Договаривающихся Сторон [...]. На этой основе и разрабатывались все положения Договора) ${ }^{18}$.

25 сентября доклад был рассмотрен на Совете. 22 октября Совет сообщил Норвегии о согласии с ее предложениями, а 21 ноября 1919 г. одобрил проект договора.

\section{Несколько слов о позиции заинтересованных}

\section{держав}

Теперь, рассмотрев официальные аргументы комиссии по Шпицбергену, хотелось бы высказать несколько дополнительных соображений, связанных с некоторыми малоизвестными фактами.

Несколько государств в одностороннем порядке уведомили Норвегию о признании ее суверенитета над этой территорией. 9 мая 1919 г. Дания сообщила норвежскому правительству, а 12 июля еще раз подтвердила, что не намерена чинить препятствий в связи с норвежскими притязаниями на Шпицберген, если Норвегия поведет себя аналогичным образом в отношении претензий датчан на Гренландию. После соответствующего решения Совета министров и закрытых (in camera) консультаций с комитетом Cтортинга по иностранным делам норвежский министр иностранных дел Нильс Клаус Илен 22 июля 1919 г. дал Копенгагену необходимые заверения. 28 июля 1919 г. датчане подтвердили свое согласие с договоренностью на такой основе ${ }^{19}$.

Тот факт, что Советская Россия не принимала участия в Парижской мирной конференции, ни в коей мере не означал, что российские интересы остались без внимания. Напротив, в Статье 10 договора содержались гарантии этих интересов: она предусматривала возможность присоединения России к соглашению, как только новое правительство, возникшее в стране после революции, будет признано договаривающимися сторонами - это произошло лишь 7 мая 1935 г, когда СССР был признан последней из великих держав, подписавших договор, Соединенными Штатами. И все же было бы упущением не упомянуть

${ }^{18}$ Commission du Spitsberg, supra. Р. 89-90 (курсив мой - Р.Э.Ф.).

${ }^{19}$ Berg. Op. cit. P. 281-283. 
об одностороннем признании СССР норвежского суверенитета над архипелагом - задолго до его присоединения к Договору и вступления последнего в силу. Это официальное признание имело столь важное значение, что мы считаем уместным полностью (in extenso) привести ноту советского торгового представителя в Норвегии А.М. Коллонтай норвежскому министру иностранных дел от 16 февраля 1924 г. $^{20}$

Министерство иностранных дел Франции еще в марте 1917 г. заявило, что поддерживает притязания Норвегии на Шпицберген, а в октябре 1918 г. подтвердило эту позицию ${ }^{21}$. Аргументы, выдвинутые в ходе представления Договора французскому парламенту перед его ратификацией в 1924 г., показывают, каким образом французы оценивали его основное содержание. Они подчеркивают значение признания суверенитета Норвегии ${ }^{22}$. В ходе обсуждения договора недвусмыс-

${ }^{20}$ Французский оригинал ноты находится в архиве министерства иностранных дел Норвегии (UD H63G 2/24, том 1, P 2 В 3/20, том 2). На норвежском языке она опубликована в норвежском издании сборника документов, подготовленного Норвежским Институтом оборонных исследований и Институтом всеобщей истории Российской академии наук (см.: Sven G. Holtsmark (ed.) Norge og Sovjetunionen 1917-1955. En utenrikspolitisk dokumentasjon, Oslo, J.W. Cappelen Forlag, 1995. P. 131). (На русском языке нота приводится по российскому изданию сборника (Советско-норвежские отношения 1917-1955, М., 1997. С. 130. - Прим. перев.). Полный текст ноты гласит (курсив мой - Р.Э.Ф.):

«Имею честь сообщить Вам, что мое Правительство принимает предложение Королевского Правительства Норвегии, как оно сформулировано а памятной записке Министерства иностранных дел от 26 сентября прошлого года, а именно, что Королевское Правительство будет официально ходатайствовать перед державами, подписавшими договор от 9 февраля 1920 г, о присоединении России к договору о Шпицбергене.

Не дожидаясь результата шагов, которые Королевское Правительство соблаговолило предпринять в этом смысле перед державами, подписавшими договор, я считаю необходимьм сообчить Вам, что отныне Правительство Союза признает суверенитет Норвегии над Шииибергенам, включая остров Медвежсий, и что вследствие этого оно в будущем не будет выдвигать возражений по поводу договора о Шпицбергене от 9 февраля 1920 г. и относящегося к нему горнорудного регламента.

Примите, господин Министр, уверения в моем высоком уважении).

См.: C.A. Fleischer, "Le Régime d'exploitation du Spitsberg (Svalbard)", Annuaire français de droit international, 1978. P. 282; Berg. Op.cit. Р. 288. Однако в книге Гейра Ульфстейна (Geir Ulfstein, The Svalbard Treaty, From Terra Nullius to Norwegian Sovereignty, Oslo, Scandinavian University Press. 1995. P. 56) анализа данной ноты не содержится. ${ }^{21}$ Berg. O. cit. P. 272-273.

${ }^{22}$ Chambre des Députés, session de 1924, Annexe au process-verbal de la séance du 11 avril 1929; вторично опубликован 26 июня 1924 г., после смены правительства, одобрен Палатой депутатов 31 июля 1924 г. (№ 39), Сенатом - 1 сентября 1924 г. (Закон 
ленно выражалась благодарность Норвегии за помощь, которую она оказала союзникам в годы войны ${ }^{23}$.

На позицию Соединенных Штатов повлиял тот факт, что Роберт Лансинг, госсекретарь в администрации президента Вильсона, был не

№ 252, Journal Officiel от 6 сентября 1924 г.). Основное содержание вступительной части доклада таково (курсив мой - Р.Э.Ф.):

«9 февраля 1920 г. в Париже Правительство Республики заключило с Американским, Британским, Датским, Итальянским, Японским, Голландским, Норвежским и Шведским Правительствами договор о признании суверенитета Норвегии над архипелагом Шиицберген, включая остров Медвежий».

Поскольку эта территория ранее считалась «ничейной землей» («terra nullius»), указывалось в докладе парламенту, «подобная ситуация привела к ряду серьезных негативных последствий с международной точки зрения», в частности в связи с отсутствием законов по защите экономической деятельности на островах.

«Учитывая тот факт, что Норвегия имеет обширные интересы на Шпицбергене, географическое расположение архипелага и связи, всегда существовавшие между островами и норвежской Короной, заинтересованные правительства единодушно решили, что самым удачным и одновременно самым справедливым решением будет передать Норвегии суверенитет над этой территорией, при условии определенных гарантий для граждан других стран».

«В связи с этим для охраны их законных прав были установлены конкретные гарантии. Более того, договор обеспечивает гражданам Договаривающихся Держав и Держав, могуших в будущем присоединиться к договору, полное равноправие в приобретении и эксплуатачии горнорудных, охотничьих и рыболовных кончессий. $B$ этих челях Статья 8 Договора предусматривает разработку Норвегией горного устава, удовлетворительного с точки зрения государств, икеющих интересы на островах. Разработанный в соответствии с этим устав был передан странам - участницам договора и одобрен ими».

«Поскольку определение политического статуса Шпицбергена, необходимость в котором ощущалась столь остро, могло, пусть и косвенно, поставить под вопрос осуществление нашими гражданами своих прав собственности за рубежом, мы сочли, что до ратификации договор от 9 февраля должен быть одобрен вами».

${ }^{23}$ Commission des Affaires étrangčres, Chambre des Députés, доклад № 371, приложенный к стенограмме заседания 30 июля 1924 г. депутатом Жозефом-Бартелеми (Р. 2122) (курсив мой - Р.Э.Ф.):

«Он [договор] узаконивает фактический суверенитет Норвегии над Шпицбергеном, существующий уже триста лет, который большинство заинтересованных держав выражают готовность признать еще с 1871 г. [...] Чем скорее мы обеспечим признание прав Норвегии, которого она ожидает от нас с понятным нетерпением и которое она уже получила от Нидерландов, Англии, Дании, Соединенных Штатов и Италии, тем яснее мы продеионстрируем зтой благородной стране, что франиузский народ не забыл об активном сочувствии, которое она проявила к нему в час величайшего испытания в его истории, и услугах, косвенно оказанных союзникаи норвежскии торговым флотом, ченою гибели 800 судов и 1200 моряков, в годы войны за счет участия в перевозках грузов». 
понаслышке знаком со шпицбергенским вопросом. Еще накануне Парижской конференции Лансинг выступал за передачу Норвегии суверенитета над архипелагом. 21 сентября 1918 г. он представил записку относительно территориальных вопросов, решение которых необходимо для обеспечения прочного мира в Европе: в пункте 28 он предлагал признать суверенитет Норвегии над Шпицбергеном ${ }^{24}$.

Позиция Великобритании на заседании Комиссии по Шпицбергену 18 июля 1919 г. формулировалась следующим образом: «поддержка требования Норвегии при одновременной защите прав своих граждан в отношении угольных шахт на Шпицбергене» ${ }^{25}$. Еще одним подтверждением важности услуг, оказанных союзникам норвежским торговым флотом в годы войны, стал тот факт, что лорд Керзон $^{26}$ первоначально поддерживал решение о предоставлении Норвегии мандата над этой территорией ${ }^{27}$. Однако министр иност-

${ }_{24}^{24}$ « бы сформулировал необходимые условия для стабильного льира следующим образом [...]: [...] Пункт двадцать восьмой - суверенитет над архипелагом Шпицберген должен быть передан Норвегии». (Robert Lansing, The Peace Negotiations - A Personal Narrative, Boston/New York, Houghton Mifflin Company, 1921. P. 195-196, курсив мой Р.Э.Ф.). Роберт Лансинг занимал пост госсекретаря с 1915 по 1921 г. По его мнению, единственно возможный вариант окончательного решения вопроса заключался в передаче суверенитета над архипелагом нейтральному скандинавскому государству ( $A J I L$, Vol. 11. 1917. Р. 763-771): при этом, как считается, он имел в виду Норвегию.

${ }^{25}$ Procuc-verbal No. 1, стенограмма заседания от 18 июля 1919 г. (см.: Documents on British Foreign Policy 1919-1939, First Series, Vol. V, London, H.M. Stationery Office. 1954. P. 44). ${ }^{26}$ Джордж Натаниэль Керзон оф Кедлстон (1859-1925) - вице-король Индии с 1898 по 1905 г., член «узкого» военного кабинета Ллойд-Джорджа, исполнял обязанности министра иностранных дел в период участия лорда Бальфура в мирной конференции. Сменил лорда Бальфура на посту министра иностранных дел в октябре 1919 г.

${ }^{27}$ Меморандум Керзона Бальфуру от 12 августа 1919 г., ibid. Р. 213 (курсив мой - Р.Э.Ф.): «[...] Прежде всего, они тем самым приобретут полезный рычаг давления и сильные позиции для обеспечения удовлетворительного решения вопроса о британских правах и защиты британских интересов. Во-вторых, мое внимание уже было привлечено к вопросу о праве Норвегии на определенное вознаграждение в связи с ее позицией в годы войны, и особенно услугами, оказанньии делу союзников норвеюскки торговьи флотои. Поддержка притязаний Норвегии на мандат над Шпицбергеном стала бы отличным способом заставить кое-кого отказаться от этой точки зрения. В-третьих, по причинам общеполитического характера было бы желательно, чтобы правительство Ее Величества поддержало такое решение, отчасти имея в виду дружеский характер англо-норвежских отношений, важность которых в полной мере проявилась во время войны, а отчасти в целях некоторой корректировки впечатления, несомненно преобладающего за рубежом, что правительство Ее Величества уже добилось для себя громадных преимуществ и привилегий, получив мандаты на территории, расположенные в других регионах мира». 
ранных дел лорд Бальфур ${ }^{28}$, находившийся в Париже, был против любого усиления нагрузки на Лигу Наций, а значит - и любого ее участия в управлении этой территорией. Он также поддерживал признание суверенитета Норвегии, сосредоточив внимание на защите прав британских граждан на «добычу полезных ископаемых» ${ }^{29}$. На этой основе британское правительство поддержало предоставление Норвегии полного суверенитета над островами, «при условии четкой договоренности о том, что британские права, интересы и претензии, как существующие, так и будущие, должны быть полностью соблюдены.

${ }^{28}$ Артур Джеймс Бальфур (1848-1930) - премьер-министр Великобритании с 1902 по 1905 г., министр иностранных дел с 1917 по октябрь 1919 г. Он является автором Декларации Бальфура (1917 г.) о создании в Палестине «национального очага» для еврейского народа. Принимал участие в Парижской мирной конференции.

${ }^{29}$ В письме Керзону от 17 августа 1919 г. (Documents on British Foreign Policy. Op. cit. Р. 221) Бальфур формулирует свою точку зрения без дипломатических экивоков (курсив мой. - Р.Э.Ф.):

«Норвежцы ухитрились убедить все другие державы, что правильным решением будет предоставить Норвегии владение островом [sic]. Мы несомненно лишимся всякой популярности в Норвегин, если эта схема потерпит крах исключительно из-за наших возражений. Во время войны из всех нейтралов Норвегия относилась к наи наиболее благосклонно и, несмотря на свою слабость, оказывала нам добрые услуги. Мне было бы жаль потерять друга, сохранявшего нам верность не только в момент успеха, но и в час испытаний; и я не могу себе представить, каких таких существенных преимушеств мы можем добиться, если выступим по этому вопросу против всего мира, за исключением Швеции - державы, которую нам уж точно не за что благодарить».

По этим причинам я намерен сосредоточить наши усилия на том, чтобы позаботиться о защите любых прав на добычу полезных ископаемых, которые у нас имеются, а также об обеспечении в полной мере нашей доли в будущих концессиях. [...]

Вероятно, следует указать и на значительное беспокойство, которое может причинить Лиге Начий управление Шпицбергеном: ведь очевидно ей придется доставить туда поличейских и судебных чиновников, построить для них дома и создать систему налогообложения, чтобы обеспечить оплату их деятельности».

В аналитической записке, приложенной к письму (Ibid. Р. 222), отмечается:

«Однако сегодня ситуация коренным образом изменилась. Норвегии удалось убедить все остальные державы, что самым простым, честным и удовлетворительным решением вопроса является передача острова [sic] под ее суверенитет. Россия - настолько, насколько различные российские группировки и политические организации, представленные в Париже, имеют право выступать от лица России - Дания и Соединенные Штаты Америки высказались в пользу норвежских притязаний, которые пользуются самой теплой поддержкой и со стороны Франции, Италии и Японии. Даже Швеция не чинит - и вряд ли станет чинить - по-настоящему серьезные препятствия, хотя в неофициальном порядке и дала понять, что, с ее точки зрения, предпочтительным решением было бы предоставить Норвегии мандат Лиги Наций». 
На первый взгляд разработанный проект Конвенции, судя по всему, неплохо обеспечивает их должную зашиту ${ }^{30}$.

Швеция первоначально отдавала предпочтение предоставлению Норвегии мандата Лиги Наций, но затем согласилась с предложенной формулой ${ }^{31}$. Кроме того, она попросила включить в повестку дня конференции вопрос о статусе Аландских островов, опасаясь, что на них могут быть возведены укрепления, и тогда «Стокгольм окажется под прицелом русских орудий» ${ }^{32} .25$ сентября Клемансо даже заявил в Палате депутатов (Chambre des Düputǔs): поскольку Норвегия получила Шпицберген, а Дания - Шлезвиг, то Аландские острова следует отдать Швеции ${ }^{33}$. Однако вынести этот вопрос на рассмотрение конференции оказалось невозможно. Когда шведский король спросил Керзона, почему обсуждать судьбу Шпицбергена было можно, а Аландских островов - нет, тот объяснил, что в случае со Шпицбергеном речь шла просто об одобрении уже достигнутого соглашения. По его мнению, единственным возможным решением было передать спор между Швецией и Финляндией на рассмотрение Совета Лиги Наций, что и произошло в $1920 r_{.}^{34}$.

${ }^{30}$ Меморандум Керзона Кабинету министров от 25 августа 1919 г. (Ibid. Р. 299; курсив мой - Р.Э.Ф.):

«[...] Если, таким образом, мы, единственные из участников мирной конференции, выступим против притязаний Норвегии, мы вызовем возмущение норвежцев, народа, с которым мы желаем поддерживать самые дружеские отношения и у которого мы 8 серьезном долгу за услуги, оказанные в годы войны. Кроме того, нет никаких гарантий, что наша отрицательная позиция в отношении норвежского суверенитета возобладает над единодушным мнением других Союзных и Присоединившихся держав в Париже. В сложившихся обстоятельствах и с учетом мнения моих коллег из Адмиралтейства, Военного министерства и Министерства торговли я рекомендую согласиться с курсом, предложенным г-ном Бальфуром, при условии четкой договоренности о том, что британские права, интересы и претензии, как существуючие, так и будучие, должны быть полностью соблюдены. На первый взгляд, разработанный проект Конвенции, судя по всему, неплохо обеспечивает их должсню зациту. Однако некоторые статьи, в особенности Статья 7, могут потребовать дополнительного уточнения, а горный устав, предусмотренный Статьей 8, необходимо будет подвергнуть самому тщательному изучению».

${ }^{31}$ Berg. Op. cit. P. 285.

${ }^{32}$ Commission de publication des documents relatifs aux origins de la guerre de 1914, Documents diplomatiques français, Serie 3, Vol. 9. P. 63. Né.: James Barros, The Aaland Islands Question, New Haven, Yale University Press, 1968. P. 18.

${ }^{33}$ Journal officiel, Chambre des Députés, Débats parlementaires, session ordinaire (сентябрь - октябрь 1919). Р. 4572. См.: Barтos. Op. cit. P. 196.

${ }^{34}$ Documents on British Foreign Poli. Op. cit., Vol. XI. P. 283-287. 
Какие же выводы мы можем сделать, рассмотрев контекст этих переговоров? Сразу же приходят на ум несколько соображений. Во-первых, стороны стремились добиться мирного и справедливого решения вопроса. Во-вторых, что не менее важно, это решение должно было быть четким и окончательным. Признание полного и абсолютного суверенитета Норвегии на условиях, сформулированных в Договоре, несомненно, являлось одним из способов достижения этих целей, но это был не просто способ добиться цели, второстепенная задача или задача, подчиненная другим. В свете вышеописанных обстоятельств признание также само по себе являлось первостепенной целью. В его основе лежали осознанный выбор и четко выраженные намерения. Сюда можно добавить и признание норвежского суверенитета Данией в одностороннем порядке в 1919 г, а также его официальное признание Советским Союзом в 1924 г. - несколько исследователей обходят вниманием эти два факта.

Эти основные соображения позволяют объяснить содержание Статьи 1 Договора, где говорится, что Высокие Договаривающиеся Стороны:

«соглашаются признать, на условиях, предусмотренных настоящим Договором, полный и абсолютный суверенитет Норвегии над архипелагом...».

Эти условия, среди прочего (inter alia), оговаривают, что:

«Суда и граждане Высоких Договариваюшихся Сторон будут допущены на одинаковых основаниях к осуществлению права на рыбную ловлю и охоту в местностях, указанных в статье 1, и в их территориальных водах» (Статья 2, § 1);

«Граждане всех Высоких Договаривающихся Сторон будут иметь одинаковый свободный доступ для любой цели и задачи в воды, фиорды и порты местностей, указанных в статье 1, они могут заниматься в них, без каких-либо препятствий, при условии соблюдения местных законов и постановлений, всякими морскими, промышленными, горными и торговыми операциями на условиях полного равенства) (Статья $3, \S 1)$;

«Они будут допущены на тех же условиях равенства к занятию всяким морским, промышленным, горным и коммерческим делом, как на суше, так и в территориальных водах, причем не может быть создана никакая монополия в отношении чего-либо и в отношении какого бы то ни было предприятия». (Статья $3, \S 2$ ). 
Разработчики международных соглашений никогда не стесняются заимствовать формулировки сушествующих договоров ${ }^{35}$. Юридическая теория и практика свидетельствуют о пользе анализа целых групп договоров по аналогичной тематике, разработанных в один и тот же период ${ }^{36}$. Как показал Борис Нольде ${ }^{37}$. война 1914-1918 гг. опрокинула традиционные методы международного торгового права. В Свальбардском договоре просматриваются некоторые характерные для того времени элементы многостороннего подхода, особенно в вопросе о свободном обороте товаров ${ }^{38}$. Кроме того, во многих двусторонних договорах уже встречалось положение о полном равенстве ${ }^{39}$. Однако, благодаря признанию полного и абсолютного суверенитета Норвегии, Договор явно отличается от многих других соглашений того времени ${ }^{40}$.

\section{Некоторые события, имевшие место после 1920 г.}

К договору, подписанному Соединенными Штатами Америки, Великобританией, Данией, Францией, Италией, Японией, Норвегией, Нидерландами и Швецией, могли присоединиться другие государства, причем данное присоединение должно было осушествляться путем уведомления французского правительства, которое является депозитарием Договора ${ }^{41}$. Одной из первых, в 1920 г., заявку на присоедине-

${ }^{35}$ P. Reuter, Introduction au droit des traités, 3 ed., rev. by Ph. Cahier, Paris. P. U.F., 1995. P. $91, \S 148$.

${ }^{36} \mathrm{Ibid}$. В частности, речь идет о технических терминах и стандартных положениях.

${ }^{37}$ Boris Nolde, "Droit et technique des traités du commerce", Recueil des Cours de l" Academie de Droit International (RCADI), 1924-ii, Vol. 3. Р. 291-462. До 1916 r. Борис Нольде являлся главным юристом Российского министерства иностранных дел.

${ }^{38}$ Cahier. Op. cit. P. 318. См., в частности, Статью 23 (е) Хартии Лиги Наций, $\$ 3$ Преамбулы к Барселонской конвенции о свободе транзита от 20 апреля 1921 г., \$1 преамбулы к Женевской конвенции о международном режиме морских портов от 9 декабря 1923 г. и § 2 преамбулы к Женевской конвенции о международном режиме железных дорог от 9 декабря 1923 г.

${ }^{39}$ Так, полное равенство в отношении судов и их грузов предусматривается Статьей 4 Договора о торговле и мореплавании между Норвегией и Бельгией от 27 июня 1910 г. (The Treaties of Nonway 1661-1966, Vol. 1, No. 156. P. 338).

${ }^{40} \mathrm{C}$ м., например, положения Версальского договора о защите Данцига, об инспекциях рыболовных судов в германских территориальных водах, администрации Саара и контроле над его угольными шахтами, или создание нескольких подмандатных территорий в соответствии со Статьей XXII (параграф 5) Хартии Лиги Наций. Не шла речь и о создании системы «открытых дверей» или «неравноправного отношения), существовавшей в отношении китайских портов в 19 веке.

${ }^{41}$ См. Статью 10 Договора. Сегодня участниками Договора являются более сорока государств. 
ние к договору подала Германия ${ }^{42}$. Острова вошли в состав Королевства Норвегии в 1925 г., когда Договор вступил в силу ${ }^{43}$. Норвежский флаг на архипелаге был поднят министром юстиции Полом Бергом в полдень 14 августа 1925 г.: торжества включали и церемониальный марш моряков с норвежских военных кораблей «Хеймдаль» и «Фарм»" ${ }^{44}$.

Статус островов зачастую рассматривался в крайне чувствительном стратегическом контексте. Статья 9 Договора предусматривает использование их территории в мирных целях:

«С оговоркой в отношении прав и обязанностей, могущих явиться для Норвегии результатом ее вступления в Лигу Наций, Норвегия обязуется не создавать и не допускать создания какой-либо морской базы в местностях, указанных в статье 1, и не строить никаких укреплений в указанных местностях, которые никогда не должны быть использованы в целях войны» ${ }^{45}$.

После нападения Германии на Норвегию в 1940 г., архипелаг был оккупирован в 1942 г. гитлеровскими войсками, а в сентябре 1943 г. находящиеся там поселения были разрушены в результате бомбардировки немецкой эскадрой, флагманом которой был знаменитый линкор «Tирпиц». В конце войны Советский Союз предъявил претензии на остров Медвежий, а также потребовал установить советсконорвежский кондоминиум (совместное владение) над остальной частью архипелага и аннулировать Договор 1920 г. Норвегия отвергла эти требования ${ }^{46}$. Вскоре после этого Норвегия вступила в НАТО

${ }^{42}$ Ulfstein $O p$. cit. P. 56.

${ }^{43}$ Как только Договаривающиеся Стороны одобрили Горный устав Шпицбергена (см. ниже).

${ }^{44}$ Berg Op. cit. P. 301.

45 Оговорка об обязанностях, вытекающих из членства в Лиге Наций, должна сегодня толковаться как ссылка на положения Устава ООН. Во французском тексте Договора употребляется выражение "buts de guerre" («цели войны»). Единственными аутентичными текстами договора являются французский и английский. Однако в русском переводе, принятом в СССР, говорится, что территории архипелага «не должны быть использованы в военных целях", а это означает, что эти территории нельзя оборонять или осуществлять на них любую военную деятельность, даже заход корабля береговой охраны. Такое истолкование не соответствует тексту Договора. См.: Holtsmark. Op. cit. Р. 439, сноска 3.

${ }^{46}$ Это требование народный комиссар иностранных дел СССР В.М. Молотов предъявил министру иностранных дел Норвегии Трюгве Ли (позднее он стал первым Генеральным секретарем ООН) в ходе ночной беседы в Кремле 12 ноября 1944 г. Запись беседы см.: Holtsmark. Op. cit. P. 340-344. (На русском языке запись опубликована в кн. «Советско-норвежские отношения» С. 361-365 - прим. перев.). 
и в декабре 1950 г. включила архипелаг в сферу действия Атлантического пакта в случае агрессии, что вызвало враждебную реакцию $\mathrm{CCCP}^{47}$. В этой напряженной обстановке Норвегия проводила последовательную политику эффективного осуществления своего суверенитета над архипелагом, включавшую, среди прочего (inter alia), заходы кораблей береговой охраны, стараясь при этом не обострять ситуацию ${ }^{48}$. В конечном итоге такая политика принесла свои плоды, поскольку разногласия уступили место фактическому признанию всех принятых мер.

В начале 1960-х гг., на основе Горного устава Шпицбергена ${ }^{49}$, норвежское правительство предоставило американской фирме CALTEX и советскому тресту «Арктикуголь» концессии на разведку нефти. Концессионеры заключили с правительством контракты, обеспечивающие получение государством отчислений от доходов, в случае если месторождения нефти будут найдены, в соответствии с правом государства на финансовое и техническое участие в их разработке по Горному уставу исходя из его собственности на земли, где действуют концессии. Геологоразведочные работы не увенчались успехом, однако этот случай является убедительным примером адаптации Горного устава к новым условиям и признания концессионерами прав собственности норвежского государства.

Далее возник вопрос о применимости Договора о Шпицбергене к океанскому пространству. Никто не возражал против того, что его действие распространяется на внутренние и территориальные воды архипелага. Договор 1920 г. устанавливает равные права на территории островов, включая территориальные воды. В нем нет никаких указаний насчет водных пространств вне территориальных вод. Новое морское право и появление современного океанского пространства привело к возникновению новых проблем и разногласий.

С 1964 г., после принятия первого законодательного акта о континентальном шельфе, Норвегия считала, что континентальный шельф простирается и на северные воды, а значит, к ним также применимо норвежское законодательство. Континентальный шельф, не прерываясь, продолжается на север от континентального побережья Норвегии, и глубина там составляет не более 500 метров. Таким образом, он

${ }^{47}$ См. советские ноты от 15 октября и 12 ноября 1951 г.: Holtsmark. Op. cit. P. 466-468, 473-475 («Советско-норвежские отношения) С. 502-504, 510-511).

${ }^{48}$ Цитировавшийся выше Доклад Стортингу № 9. С. 27-28.

${ }^{49}$ Устав был принят Норвегией 7 августа 1925 г. в соответствии со Статьей 8 Договора о Шпицбергене. 
является естественным продолжением основной континентальной территории Норвегии. Критерий пригодности для эксплуатации, установленный Женевской конвенцией 1958 г. о континентальном шельфе, также соблюден ${ }^{50}$. Подобный подход вызвал оговорки со стороны СССР, а также, особенно в условиях нефтяного кризиса 1973 г, со стороны других государств. Страны - члены НАТО, формулируя свои оговорки, тем не менее принимали во внимание стратегические соображения.

Ряд сложных вопросов возник во второй половине 1970-х гг., в связи с созданием экономических зон протяженностью в 200 морских миль ${ }^{51}$. Новое морское право разрешает, а в какой-то степени и предписывает, управление природными ресурсами.

\section{Истолкование сферы действия Договора о Шпицбергене}

Ниже мы даем лишь очень краткий обзор некоторых элементов истолкования Договора $1920 \Gamma_{.}^{52}$. Венская конвенция о договорном праве от 23 мая 1969 г. как таковая не может применяться в отношении данного Договора, прежде всего потому, что она не имеет обратной силы - этот принцип сформулирован в ее Статье 4. Впрочем, это не мешает Международному суду толковать более ранние договоры в свете положений, содержащихся в Статьях 31-33 Венской конвенции, связанных с международным «обычным правом» в области толкования договоров $^{53}$. Не является препятствием и тот факт, что несколько государств,

${ }^{50}$ Его заменили критерии, сформулированные в Статье 76 Конвенции ООН по морскому праву, принятой в Монтего Бэй 10 декабря 1982 г. и вступившей в силу 16 ноября 1994 г., 1833 United Nations Treaty Series 3.

${ }^{51}$ L. Luccini, M. Voelckel, Droit de la mer, Vol. 1, Paris, Pedone. 1990. P. 479-480; R.J. Dupuy, D. Vignes (eds), Traité du nouveau droit de la mer, Paris/Brussels, Economica/ Bruylant, 1985. P. 470, 475.

${ }^{52} \mathrm{~B}$ рамках данной статьи нет ни возможности, ни необходимости теоретических обсуждений, связанных с договорами, создающими «объективную ситуацию», т.е. затрагивающих третьи страны. На практике эта проблема является частью вопроса об обычаях, запретах, признании, принятии, утверждении исторических прав, и прежде всего - молчаливом согласии (см.: Р. Reuter Op. cit. P. 112, § 188, Ph. Cahier. Op. cit. P. 139, и P. Reuter, Droit international public, 6 ed., Paris, P.U.F., 1983. P. 97, 207). Болеe того, подобная дискуссия не представляет интереса с точки зрения заинтересованных государств.

${ }^{53}$ Решение от 3 февраля 1994 г. по делу о Территориальном споре между Ливийской Араб́ской Джаиахирией и Чадом, ICJ Reports 1994. Р. 21, § 41; Предварительный протест - Решение от 12 декабря 1996 г. по делу о Нефтяных платформах (Исламская Республика Иран против Соединенных IUтатов Америки), ICJ Reports 1996 (II). P. 812, 
в том числе и Норвегия, не присоединились к Конвенции ${ }^{54}$. Но это не означает, что при толковании прежних договоров о режимах определенных территорий можно игнорировать временные ограничения, независимо от того факта, что последние могут и не действовать при толковании договоров в других правовых сферах, например законодательстве о международных организациях или правах человека.

Толкование должно основываться прежде всего на тексте самого договора. Общепринятые правила истолкования требуют, чтобы понятия, используемые в тексте договора, рассматривались в их «естественном смысле», т.е. в том значении, которое они обычно имеют в юридической лексике ${ }^{55}$. Положения Договора о Шпицбергене сформулированы с абсолютной ясностью. В Статьях 2 и 3, связанных с морским пространством, недвусмысленно указывается, что речь идет о территориальных водах.

Приоритетное значение текста самого договора установлено прецедентным правом:

«Таким образом, Суд в первую очередь должен по формулировкам данной статьи установить, в чем состояли намерения договаривающихся сторон; после этого он может рассмотреть вопрос о том, следует ли - и если да, то в какой степени - принимать в этой связи во внимание другие факторы, помимо формулировок Договора» ${ }^{56}$.

В соответствии с принципами толкования договоров, формулировки договора должны также восприниматься «в их контексте и в свете его [договора] предмета и целей» ${ }^{57}$. В преамбулах договоров содержатся положения, не имеющие нормативного характера, но тем не менее говорящие об общих соображениях, связанных с целями договора. В данном случае в преамбуле к Договору 1920 г. указывается:

«Желая, наряду с признанием суверенитета Норвегии над архипе§ 23; Решение от 13 декабря 1999 г. по делу об Острове Касикили/Седуду (Ботсвана/ Haмибия), ICJ Reports 1999. Р. 1059, § 18; Решение от 27 июня 2001 г. по делу Лагранд (Германия против Соединенных Штатов Америки) § 99.

${ }^{54}$ Тем не менее см. особое мнение Судьи Оды по делу об Острове Касикили/Седуду (Ботсвана/Намибия), ICJ Reports 1999. P. 1118, § 4.

${ }^{55} \mathrm{~J}$. Combacau, Le droit des traités, Paris, P.U.F., Que sais-je? 1991. P. 33.

${ }^{\text {s6 }}$ PCIJ, Series $B$, No. 12. P. 19 (рекомендация от 21 ноября 1925 г. по параграфу 2 Статьи 3 Лозаннского договора (о граниче между Туриией и Ираком)). См. также РСІЈ, Series B, No. 2. P. 22 (рекомендация от 31 июля 1922 г. о Компетенции МОT (Межсународной организачии труда) в отночении международного регулирования условий труда лич, занятых в сельском хозяйстве).

${ }^{57}$ Статья 31 § 1 Венской конвенции. См.: Reuter. Op. cit. P. 90, § 145. 
лагом Шпицберген, включая о. Медвежий, видеть установление в этих местностях справедливого режима управления, в целях обеспечения их развития и мирного использования.... ${ }^{58}$.

Что означает формулировка о «справедливом режиме управления, в целях обеспечения их развития и мирного использования»? Хотя речь здесь идет прежде всего о подготовке Горного устава, предусмотренного Статьей 8 , эти положения обнаруживают удивительное сходство с формулировками преамбулы Конвенции ООН 1982 г. о морском праве (см. ниже).

Анализ подготовительной работы над договором и обстановки, в которой он был заключен, также может помочь при его истолковании - если требуется подтвердить смысловую интерпретацию его положений, а таюже в случае, если договор сформулирован неясно и двусмысленно, или его истолкование приводит к абсурдному и нелогичному результату ${ }^{59}$. Хотя к Договору 1920 г. эти случаи не относятся, мы уже обрисовали общую обстановку, характерную для периода, когда этот Договор был заключен. Здесь же достаточно упомянуть о недвусмысленном заявлении председателя Комиссии по Шпицбергену о масштабе ограничений норвежского суверенитета:

«Все исключения из принципа суверенитета содержатся в готовящемся Договоре; во всех других вопросах должен применяться принцип суверенитета Норвегии» ${ }^{60}$.

Подобный подход соответствует общепринятым нормам, связанным с концепцией государственного суверенитета. Принцип исключительной юрисдикщии государства над территорией выразился в решении Арбитражного суда, принятом в 1935 г. относительно острова Пальмас, где говорилось, что <территориальный суверенитет, как уже отмечалось, связан с исключительным правом деятельности государства» ${ }^{61}$, и давался

${ }^{58}$ Французский текст преамбулы гласит: Désireux, en reconnaissant la souveraineté de la Norvčge sur l'archipel du Spitsberg, y compris l'ile aux Ours, de voir ces regions pourvues d'un régime equitable proper $\dot{r}$ en assurerla mise en valeur et l'utilisation pacifique". B аутентичном французском тексте абсолютно четко указывается, что между признанием суверенитета Норвегии и установлением справедливого режима управления этими территориями в целях обеспечения их развития и мирного использования нет никакого противоречия.

59 Этот принцип отражен в Статъе 32 Венской конвенции по договорному праву.

60 "Toutes les dérogations ŕ la souveraineté se trouve dans le Traité en preparation, pour le surplus, il y a lieu d'appliquer la souveraineté de la Norvčge". Commission du Spitsberg, supra. P. 60.

${ }^{61}$ Арбитражное решение по острову Пальмас (Миангас), UNRIAA, Vol. II. P. 829. 
анализ этого понятия, который с тех пор считается классическим:

«Этому праву сопутствует долг: обязанность защищать в рамках данной территории права других государств, особенно их права на целостность и нерушимость, в мирное и военное время, а также права граждан любого государства на зарубежной территории, о которых это государство может заявить) ${ }^{62}$.

Решение, принятое Постоянной палатой международного правосудия (ППМП) в 1923 г. по делу о судне «Уимблдон», показывает, какой вес придается в юриспруденции ограничительному толкованию понятия о пределах территориального суверенитета:

«От Суда не требовалось занять определенную позицию по вопросу, к тому же весьма противоречивому, о том, действительно ли в области международного права существуют принудительные обязанности, аналогичные обязанностям, предусмотренным частным правом. Независимо от того, связано ли германское правительство принудительной обязанностью или договорным обязательством, принятым в отношении держав, в чью пользу сформулированы условия Версальского договора, обеспечить свободный доступ в Кильский канал, как в мирное, так и в военное время, всем кораблям всех стран, факт остается фактом: Германии приходится идти на серьезное ограничение оспариваемых в данном случае суверенных прав, которыми она обладает в отношении Кильского канала. Этот факт является достаточной причиной для ограничительного толкования, в случае наличия сомнений, положения, создающего подобное ограничение. Однако Суд счел себя обязанным остановиться на той черте, где так называемое ограничительное толкование вступает в противоречие с недвусмысленными формулировками статьи и приводит к ликвидации четко предоставленных ею прав ${ }^{63}$.

Решение ППМП по делу о Мемельском крае заслуживает особого внимания в свете возможных аналогий со Шпицбергеном. Мемель немецкое название порта Клайпеда на Балтике, некогда принадлежавшего Пруссии. Конвенция 1924 г. о статусе края признавала суверенитет Литвы над этой территорией в обмен на предоставление ее органам власти полномочий автономии. ППМП подтвердила, что, в случаях, когда превышаются пределы конкретно сформулированных

\footnotetext{
${ }^{62}$ Ibid. P. 839.

${ }^{63}$ Решение № 1 по делу о судне «Уимблдон» (17 августа 1923 г.), PCIJ, Series $A$, No. 1 . Р. 24 (курсив мой - Р.Э.Ф.).
} 
положений об исключениях из принципа суверенитета, применяются общие принципы суверенитета:

«Суверенные полномочия одной стороны (Литвы) и другой стороны (Мемельского края) являются понятиями совершенно различного порядка в том смысле, что осуществление полномочий последней стороны требует наличия юридического правила, которое нельзя считать автоматически подразумеваемым при отсутствии соответствующих упоминаний в акте о предоставлении автономии или в результате истолкования, призванного расширить автономию за счет покушения на осуществление суверенных полномочий» ${ }^{64}$.

По другому делу, связанному с ограничениями территориального суверенитета Франции в соответствии с договорами, заключенными в 1815 г., ППМП подтвердила, что «в случае возникновения сомнений положение о пределах суверенитета должно толковаться ограничительно ${ }^{65}$. Судья О.И. Сеферьяд распространил эту точку зрения на все другие случаи:

«В соответствии с общим принципом, единодушно признанным теорией международного права, все договоры «предусматривающие принудительные обязанности, должны толковаться ограничительно, с тем, чтобы из-за принудительной обязанности, представляющей собой исключительное право, связанное с территорией иностранного государства, суверенитет данного государства ограничивался как можно меньше». Это поистине один из общих принципов международного права, признанный всеми цивилизованными странами, и один из общих принципов, которые Суд обязан применять в соответствии со Статьей 38 своего Статута» ${ }^{66}$.

Ограничительное толкование пределов территориального суверенитета на Шпицбергене в контексте сферы действия Договора признается и теоретиками-правоведами, пусть и не единодушно ${ }^{67}$. Потому-то

${ }^{4}$ Решение от 11 августа 1932 г. об Истолковании статута Мемельского края, РСІЈ. Series $A / B$, No. 49. P. 313.

${ }^{65}$ Решение от 7 июня 1932 г. о Свободных зонах Верхней Савойи и района Гекс (Франция/Швейцария), PCIJ Series $A / B$, No. 46. Р. 167. См. распоряжение от 6 декабря 1930 г. по тому же делу, PCIJ Series $A$, No. 24. Р. 12.

${ }^{66}$ Решение от 8 октября 1937 г. по делу о Маяках на Kрите и Caмосе, PCIJ, Series $A / B$, No. 71. P. 137-138.

${ }^{67}$ Кари Хакапяя (См.: Kari Hakapää, “Some Observations on the Arctic Waters and the New Law of the Sea”, Juridica Lapponica, No. 6, Rovaniemi, 1990. P. 72-73) подтверждает, что противоположная «аргументация может завести слишком далеко не только разработчнков международного документа, но и сами обязательства по договору. К при- 
представляется полезным подробнее остановиться на том, что говорит по этому вопросу прецедентное право.

Два решения арбитражных судов - по делу «Petroleum Development Ltd. nротив шейха Aбу-Даби"68, принятое в сентябре 1951 г., и по делу "Petroleum Development (Kamap) против правителя Катара» ${ }^{69}$, принятое в апреле 1950 г., - оказали значительное влияние на теорию пра$\mathrm{Ba}^{70}$. Согласно этим решениям, соглашения о концессиях, предоставленных соответственно в 1939 и 1935 гг. и охватывавших воды, окружающие территории данных стран, нельзя было истолковывать таким образом, чтобы они распространялись на континентальный шельф, в то время это была абсолютно новаторская концепция.

Утверждается $^{71}$, что решение Международного суда (МС) по делу о Континентальном шельфе Эгейского моря ${ }^{72}$ позволяет прийти к другому выводу, поскольку выражение «территориальный статус Греции», содержавшееся в оговорке к соглашению ${ }^{73}$, было истолковано судом как распространяющееся и на континентальный шельф. Тем самым Суд применил так называемый метод «мобильной ссылки», истолковывая содержащуюся в договоре концепцию в свете ее понимания в момент вступления в действие, а не в свете ее первоначального понимания (так называемый метод «фиксированной ссылки» $)^{74}$. Суд, однако, не счел устаревшими прецеденты, созданные делами по Абу-Даби и Катару. Напротив, он дал четкую ссылку на эти дела, но подчеркнул «фундаментальное различие» между ними и формулировкой оговорки к соглашению об урегулировании споров, связанных с территориальным статусом государ-

меру, соответствующая формулировка Договора о Шпицбергене имеет недвусмысленный характер: она относится только к территориальным водам, а это понятие с любой юридической точки зрения отличается от понятия континентального шельфа. Для расширительного ее толкования представлялось бы необходимым заручиться одобрением заинтересованных сторон».

${ }^{68} / I R$, Vol. XVIII (1951). P. 144.

${ }^{69} \mathrm{Ibid}$. P. 161.

${ }^{70}$ C.A. Fleischer. Op. cit. Р. 296, и, в особенности, Petroleumsrett, Oslo, Universitetsforlaget, 1983. P. 179-234; J.P.A. Bemhardt, "Spitsbergen: Jurisdictional Friction over Unexplored Oil Reserves", California Western International Law Journal, Vol. 4, Winter 1973. P. 115. ${ }^{1}$ Ulfstein. Op. cit. P. 325.

${ }_{72}$ Дело о континентальном шельфе Эгейского моря, ICJ Reports 1978. P. 32-33, § 77.

${ }^{73}$ Статья 17 Общего Акта 1928 г. о мирном урегулировании международных споров. ${ }^{74}$ CM.: Nguyen Quoc Dinh, Patrick Daillier and Alain Pellet, Droit international public, 7 ed., Paris, LGDJ. 2002. P. 262-263, § 169. 
ства ${ }^{75}$. Можно добавить, что общее понятие «территориального статуса» отличается чрезвычайной широтой. Интерпретация подобных понятий в оговорке к договорному обязательству, подлежащему юрисдикции суда, по методу lato sensu - или «мобильной ссылки» - действительно соответствует принципу ограничительного толкования пределов территориального суверенитета. Это также соответствует требованию о строгом взаимном соответствии между толкованием и применением, содержащемуся в рекомендательных положениях $\S 2$ Статьи 36 Статута Международного суда ${ }^{76}$. Суд последовательно придерживался этого подхода при толковании обязательств, предусматривающих рассмотрение в суде. Таким образом, решение 1978 г. не связано ни с новым подходом со стороны Суда ${ }^{77}$, ни с отказом от принципов толкования, рассмотренных выше. Наоборот, оно скорее усиливает эти положения.

В весьма специфическом контексте законодательства Европейского сообщества возник вопрос о сфере применения юрисдикции сообщества за пределами территориальных морских вод ${ }^{78}$. Он, однако, касается толкования конкретных формулировок подзаконных актов Сооб-

${ }^{75}$ ICJ Reports 1978. Р. 32, § 77. Суд установил, что:

«С точки зрения оценки намерений одной из сторон, заключивших правовой акт, существует фундаментальное различие между предоставлением права на разведку и эксплуатацию на конкретной территории в рамках концессии и формулировкой оговорки к соглашению, согласно которой государство исключает споры, связанные с его территориальным статусом, из обязательной процедуры урегулирования. Вполне можно предположить, что лицо, передающее права на ценную собственность другому лицу, намеревается лишь передать ему права, которыми он обладает в данное время, но, по мнению Суда, если государство, соглашаясь подчиниться обязательной процедуре мирного урегулирования, исключает из сферы действия этого соглашения категорию споров, которые, хотя и связаны с четко оговоренной тематикой, носят общий характер, то это совершенно иной случай. Как только было определено, что выражение «территориальный статус Греции» использовалось в акте о присоединении Греции к договору в качестве общего понятия, охватывающего любые вопросы в пределах концепции территориального статуса, принятой в общем международном праве, неизбежно возникает предположенис, что его смысл должен был эволюционировать вместе с правом и соответствовать значению, которое вкладывает в это выражение действующее законодательство в любой конкретный момент».

${ }^{76}$ Решение от 6 июля 1957 г. по делу о Некоторьх норвежских займах (Франция проmuв Hopвezuu), ICJ Reports, 1957. Р. 23.

${ }^{77} \mathrm{Cм}$. также решение от 4 декабря 1998 г. по делу о Юрисдикиии рыболовства (Испамия против Канады), ICJ Reports, 1998. Р. 432, §§ 44-46.

${ }^{78}$ См. в особенности дело № 61/77 от 16 февраля 1978 г. «Еврокомиссия против Ирландии», ECCJ Reports 1978. P. 417, §§ 45-50. 
щества, принятых одним из его институтов в свете законодательства Сообщества. Подобные действия следует четко отличать от толкования договоров, представляющего собой проявление совместной воли договаривающихся сторон на основе принципов межгосударственного права ${ }^{79}$.

Как выразился Судья Беджауи:

«Поэтому, главной основой для толкования договора является «фиксированная ссылка» на международное законодательство, действовавшее в момент его заключения. «Мобильную ссьлку» на законодательство, возникшее позднее, можно рекомендовать лишь в исключительных случаях вроде того, что мы будем рассматривать» ${ }^{80}$.

Устанавливая приоритет метода «фиксированной ссылки» в качестве одной из мер предосторожности, Беджауи подчеркивает необходимость соблюдения принципа pacta sunt servanda (договоры должны соблюдаться) и «юридической безопасности» в межгосударственных отношениях. Он утверждает, что «определение» концепции не следует путать с «законом», применимым к этой концепции, и недвусмысленно предостерегает, что «толкование» договора нельзя смешивать с его «ревизией» ${ }^{81}$.

Особую актуальность в этой связи имеет арбитражное решение 1989 г. по делу об Определении морской граничы между Гвинеей-Бисау и Сенегалом ${ }^{82}$. Арбитражный суд счел, что соглашение 1960 г. следует толковать в свете законодательства, действовавшего на момент его заключения, и что необходимость применения данного аспекта «закона временного соответствия» в данном случае подтверждается прецедентами в области морского права. «В свете текста [соглашения],

${ }^{79}$ Достаточно напомнить об известном решении Европейского суда по делу «Коста nротив ENEL», где указывается, что, в отличие от обычных международных договоров, договор об учреждении ЕЭС создал «собственную юридическую систему», а законодательство, проистекающее из этого договора - самостоятельного законодательного источника, имеет «особый и оригинальный характер». Дело № 6/64, 15 июля 1964 г., ECCJ Reports 1964. P. 1141.

${ }^{80}$ Особое мнение Судьи Беджауи в связи с решением от 25 сентября 1997 г. по делу о Проекте «Бабчиково-Надьмарот», ICJ Reports 1997, § 8.

${ }^{81}$ Ibid., $\S \S 5$ ff. P. 121 ff. См. также раздел Oppenheim's International Law (Robert Jennings and Arthur Watts (eds) Ninth Ed., Longman, 1996. P. 1281-1282) о так называемом «законе временного соответствия", т.е. необходимости толковать акт в свете общих правил международного законодательства, действовавших на момент его заключения.

${ }^{82}$ Арбитражное решение от 31 июля 1989 г., $I L R$, Vol. 83, 1990. Р. 1. Работа Ульфстейна (Ulfstein. Op. cit.) не содержит его анализа. 
а также применения принципов закона временного соответствия) Суд постановил, что действие соглашения не должно распространяться на такие определения морского пространства, которых в 1960 г. еще не существовало ${ }^{83}$ :

«Так, лишь совсем недавно Международный суд подтвердил, что правила, относящиеся к «исключительной экономической зоне», могут рассматриваться как часть общего международного права по этому вопросу (ICJ Reports 1982. P. 74, ICJ Reports 1984. P. 294, ICJ Reports 1985. Р. 33). Толкование соглашения, заключенного в 1960 г, таким образом, чтобы оно распространялось и на разграничение таких территорий, как «исключительная экономическая зона», означало бы реальное изменение его текста, но, в соответствии с известным предписанием Международного суда, делом суда является истолкование договоров, а не их ревизия (ICJ Reports 1950, Р. 229, ICJ Reports 1952, P. 196, ICJ Reports 1966, Р. 49). В данном случае нас интересует не эволюция содержания, или даже рамок, понятия морского пространства, сушествовавшего в международном праве в период заключения Соглашения 1960 г., но фактическое отсутствие в международном праве такого понятия морского пространства, как «исключительная экономическая зона», на момент заключения Соглашения 1960 г.».

И наоборот:

«Учитывая тот факт, что в действующем международном законодательстве в 1960 г. уже существовало понятие «континентального шельфа», а тогдашнее определение концепции морского пространства включало указанный динамический критерий, можно сделать вывод, что франко-португальское соглашение разграничивает континентальный шельф между Сторонами во всем объеме нынешнего определения этого морского пространства».

В своем особом мнении Судья Беджауи также указывает:

«Очевидно, здесь необходимо проявлять осторожность, ведь не стоит забывать, что принцип uti possidetis (как ты владеешь, формула интердикта, означающая, что соответствующая сторона может сохранить за собой то, что она захватила. - Прим. ред.) представляет собой исключение в отношении последствий договоров, а значит - и исключение, ограничивающее принцип государственного суверенитета) ${ }^{84}$.

\footnotetext{
${ }^{83}$ Ibid., $\$ 85$.

${ }^{84}$ Ibid., §40. Он также утверждает, что ни ИЭЗ, ни континентальный шельф нельзя рассматривать как территории, на которые распространяется действие Статьи 53 конституции Франции (Ibid., §39).
} 
Вышеописанный вклад прецедента 1985 г. в определение новых морских пространств вплотную подводит нас к анализу последствий вступления в силу Конвенции $\mathrm{OOH}$ по морскому праву.

\section{Новое морское право - приоритет Конвенции}

В Статье 55 Конвенции исключительная экономическая зона протяженностью в 200 морских миль определяется как акватория, «прилегающая к территориальным водам, но лежащая за их пределами, подпадающая под действие особого правового режима, устанавливаемого данным Разделом [Конвенции], в рамках которого права и юрисдикция прибрежного Государства а также права и свободы других Государств, определяются соответствующими положениями данной Конвенции». «Особый правовой режим» - новая формулировка; он фундаментальным образом отличается от режима территориальных вод и не носит территориального характера. В этой формулировке подчеркиваются не только исключительные права прибрежного государства, но и конкретные обязанности и ответственность этого государства, в том числе ("inter alia") и в отношении прав и свобод других государств. Таким образом, Конвенция устанавливает параллельное соотношение между правами и обязанностями прибрежного государства ${ }^{85}$. Этот режим обеспечивает давнюю потребность в разумной, эффективной эксплуатации природных ресурсов в условиях четкого контроля ${ }^{86}$. Помимо обязательств по надзору, прибрежное государство должно обеспечивать оптимальную эксплуатацию рыбных ресурсов и не допускать их истощения из-за чрезмерно интенсивного вылова. Кроме того, в его обязанности входит защита и сохранение морской экологии ${ }^{87}$. Как отмечает Комбако:

«По условиям Конвенции Монтего Бэй, широкие полномочия в сфере одностороннего регулирования, предоставляемые прибрежному Государству, не имеют, однако, территориального характера, а скорее относятся к функциональной юрисдикции. Эта функциональность проявляется и в обязанности сотрудничать с другими государствами) ${ }^{88}$.

\footnotetext{
${ }^{85}$ См. сноску 50. См. таюже: L. Lucchini and M. Voelckel. Op. cit. P. 228-230.

${ }^{86} \mathrm{Cм}$.: Law and Order in the Oceans («Законность и порядок в океанах») - публикацию Отдела океанов и морского права Управления ООН по юридическим делам (93391October 1993 - 3M). P. 30-31.

${ }^{87}$ Статья 192 Конвенции.

${ }^{88}$ J. Combacau, S. Sur, Droit international public, 2 ed., Paris, Montchrestien, 1999. P. 499.
} 
В ходе рассмотрения спора о Рыболовстве в Заливе Святого Лаврентия Арбитражный суд отмечает: «похоже, что эти полномочия по управлению природными ресурсами, постоянно сочетающиеся в положениях Конвенции с идеей их сохранения, не имеют иных целей, кроме сохранения этих ресурсов; судя по всему, они прежде всего представляют собой административные функции, которые, как отныне считается, лучше всего способно выполнять прибрежное Государство, но которые остаются функциями, соответствующими всеобщим интересам» ${ }^{89}$.

На сегодняшний день к Конвенции официально присоединились две трети стран мира. Стоит отметить и ее огромное влияние на «обычное право» - до такой степени, что правила, установленные даже теми государствами, что не являются участниками Конвенции, аналогичны, по крайней мере в основном, положениям этого документа ${ }^{90}$. Государства-участники обязаны соблюдать положения $\S \S 2-4$ Статьи 311 , требующие совместимости любых других конвенций и международных соглашений с данной Конвенцией ${ }^{91}$ :

«2. Данная Конвенция не должна изменять права и обязанности государств-участников, вытекающие из других соглашений, совместимых с данной Конвенцией, и не затрагивающих осуществления другими государствами-участниками своих прав и выполнения обязательств в соответствии с данной Конвенцией.

3. Два или более государств-участников могут заключать соглашения, меняющие или приостанавливающие действие положений данной Конвенции, применительно только к отношениям между ними, при условии, что подобные соглашения не касаются положений, отход от которых несовместим с эффективным осуществлением предмета и целей данной Конвенции, а также при условии, что подобные соглашения не затронут применения воплощенных в ней основных принципов, и если положения данных соглашений не повлияют на осуществление другими государсївами-участниками своих прав и выполнение обязательств в соответствии с данной Конвенцией.

${ }^{89}$ Арбитражное решение от 17 июля 1986 г. (Канада/Франция), UNRIIAA, Vol. XIX. Р. 223-296, в особенности Р. $256, \S 50$.

${ }^{90}$ Tullio Treves, "L'Etat du droit de la mer ŕ l'approche du XXI-čme sičcle", Annuaire du droit de la mer, Vol. V, 2000. P. 124.

91 Это положение является более радикальным по сравнению с правилами применения серии договоров по одной и той же тематике, сформулированными в $\$ 3$ Статьи 30 Венской конвенции по договорному праву. См.: Reuter. Op. cit. P. 119, § 201. 
4. Государства-участники, намеренные заключить соглашение, упомянутое в пункте 3, должны через депозитария Конвенции уведомить другие государства-участников о своем намерении заключить соглашение и об изменениях или приостановках, которые оно предусматривает. $[\ldots]\rangle$

Если бы положения Договора 1920 г. применялись за пределами территориальных вод, были бы они совместимы с правами и обязанностями, вытекающими из нового морского законодательства? Особая правовая система управления океанскими пространствами применялась бы к нему, согласно § 2 Статьи 311 Конвенции Монтего Бэй, если бы его положения нарушали права государств-участниц в рамках Конвенции или мешали бы выполнению ими своих обязательств в соответствии с ней.

Достаточно упомянуть лишь некоторые характеристики Договора 1920 г., чтобы стало ясно - он плохо совмещается или вообще несовместим с системой, которую устанавливает Конвенция. Во-первых, Договор открыт для ратификации любым государством ${ }^{92}$. В 1920 г. в мире сушествовало намного меньше государств, чем сегодня. Открытый характер Договора способствовал быстрому и окончательному решению вопроса о статусе островов и укреплению этого статуса на международной арене. Если бы присоединение к Договору гарантировало доступ к ресурсам новых океанских пространств, управление ими в соответствии с Конвенцией было бы просто невозможно. Статья 62 в особенности предполагает разумное и оптимальное управление биологическими ресурсами на основе определенных критериев. Аналогичным образом Горный устав был разработан в ответ на конкретные нужды горнодобывающей деятельности, предусмотренной Договором. Установленные на территории архипелага чрезвычайно жесткие налоговые и таможенные ограничения полностью исключают, к примеру, перечисление доходов в бюджет континентальной Норвегии ${ }^{93}$. Подобные ограничения не допускали бы любой эксплуатации континентального шельфа.

Подобным же образом Конвенция обязывает прибрежное государство соблюдать установленные ею правила распределения любых финансовых излишков в соответствии с особыми критериями, прежде всего на нужды развиваюшихся стран, а также государств, лишенных

\footnotetext{
${ }^{92}$ Статья 10 Договора.

${ }^{93}$ Статья 8 Договора.
} 
выхода к морю или имеюших неблагоприятное географическое расположение ${ }^{94}$. Критерии, предусмотренные этим особым правовым режимом, совершенно отличны от тех, что устанавливает Договор 1920 г.

Однако можем ли мы говорить о несовместимости между применением режима Конвенции в полном объеме за пределами территориальных вод, с одной стороны, и предметом и целями Договора 1920 г. - с другой? Мы уже отметили определенную аналогию между целями, декларированными в преамбуле обоих документов. Сходство между их текстами, даже с точки зрения употребляемых выражений, просто поражает. В преамбуле Конвенции говорится:

«[...] Осознавая тот факт, что проблемы океанского пространства тесно взаимосвязаны и должны рассматриваться как единое целое,

Признавая желательным установление, посредством данной Конвенции, с должным учетом суверенитета всех Государств, правового порядка на морях и океанах, способствующего международным связям, и обеспечению .иирного использования .иорей и океанов, справедливой и эффективной эксптуатаиии их ресурсов, сохранению их биологических ресурсов, а пакже изучению, заиципе и сохранению .иорской природной среды.

Учитывая, что достижение этих целей будет способствовать пракmическому установ.лению справед.пиого и равноправного экономического порядка, принимающего во внимание интересы и потребности человечества в целом и, в частности, особые интересы и потребности развивающихся стран, как имеющих, так и не имеющих выхода к морю,

[...] Считая, что кодификация и поступательное развитие морского права, достигнутое в данной Конвенции, будет способствовать укреплению мира, безопасности, сотрудничества и дружеских отношений между всеми странами в соответствии с принципами справедливости и равноправия, а также экономическому и социальному прогрессу всех народов мира, в соответствии с Целями и Принципами Организации Объединенных Наций, изложенными в ее Уставе, $[\ldots]$ ) (курсив мой - Р.Э.Ф.).

Проявившаяся в договоре 1920 г. забота об окончательном решении вопроса о статусе островов на основе полного и абсолютного суверенитета Норвегии в соответствии с условиями Договора совпадает с принципами нового морского права. Суверенитет Норвегии признан всем международным сообществом. Таким образом, как прибрежное

${ }^{94}$ Статьи 62, 69 и 70 Конвенции. 
государство, Норвегия имеет право создать вокруг архипелага экономическую зону и осуществлять свою юрисдикцию над континентальным шельфом, тем более что он является естественным продолжением ее континентальной территории. Согласно морскому праву, Норвегия имеет полномочия устанавливать правила, в принудительном порядке обеспечивать их соблюдение и осуществлять свою юрисдикцию. Она обладает функциональной компетенцией на одностороннее регулирование. Сохранение видов и оптимальная эксплуатация ресурсов с учетом самых надежных научных данных являются задачей прибрежного государства.

В любом случае Норвегия обязана обеспечить ответственное управление ресурсами на этой основе. Она постоянно отстаивает свое право прибрежного государства на осуществление национальной юрисдикции над рыболовными промыслами в зоне протяженностью в 200 морских миль у побережья Шпицбергена. Эти полномочия, права и обязанности она не может разделить с каким-либо другим государством.

По мнению Норвегии, положения Договора о Свальбарде неприменимы за пределами территориальных вод архипелага. Таким образом, правила равноправия не распространяются на океанские пространства за пределами территориальных вод. В декабре 1976 г., одновременно с Советским Союзом, Норвегия специальным законом установила экономическую зону протяженностью в 200 морских миль. После двухлетнего ожидания, в июле 1977 г., на основе этого законодательства она создала двухсотмильную рыболовную зону вокруг Шпицбергена ${ }^{95}$. - Учитывая различия во мнениях относительно применимости Договора на этой территории, Норвегия, таким образом, предпочла, впредь до особого уведомления, создать двухсотмильную рыбоохранную зону с недискриминационным режимом, а не исключительную экономическую зону. При этом она исходила из следующей предпосылки: имея возможность сделать больше, можно с таким же успехом ограничиться и меньшим. Эта мера, принятая в 1977 г. ${ }^{96}$, доказала свое жизненно важное значение в деле защиты рыбных ресурсов и устойчивого развития уязвимых видов морской фауны. Все это было бы невозможно без эффективного регулирования и контроля. Управление ресурсами континентального шельфа также требует весьма жесткого регулирова-

\footnotetext{
${ }^{95}$ Fleischer. Op. cit. P. 274-300.

${ }^{96}$ Королевский указ от 3 июня 1977 г; см. также закон об экономической зоне Норвегии от 17 декабря 1977 г.
} 
ния, особенно в целях защиты уникальной и крайне чувствительной природной среды.

Верховный суд Норвегии вынужден был наложить штрафы за незаконное рыболовство на два судна, плававших соответственно под панамским и исландским флагами ${ }^{97}$. Суд установил, что:

«никто не оспаривает полномочий Норвегии на создание экономической зоны вокруг Свальбарда и введение в этой зоне мер регулирования и ограничения, в том числе и в области рыболовства.

Апеллянты заявляли, что Договор о Свальбарде - с его требованием о равном отношении - распространяется и на экономическую зону рыбоохранную зону - и что ныне действующие правила регулирования рыболовства противоречат этому требованию о равном отношении».

Суд отметил, что, по мнению норвежской стороны, Договор неприменим за пределами территории и территориальных вод архипелага и что это мнение оспаривается некоторыми государствами. Однако он не счел необходимым вдаваться в подробности вопроса о географических рамках Договора, поскольку «я в любом случае не считаю, что Норвегия каким-либо образом отказалась от своих обязательств по Договору, введя регулирование промысла трески» ${ }^{98}$. В рамках указанного регулирования ловить треску позволяется рыбакам из стран, традиционно занимавшихся промыслом трески в этих водах. Ни у Панамы, ни у Исландии таких традиций не было. Суд счел, что:

«В рыбоохранной зоне доступ к ресурсам трески выделялся - и нормировался - таким образом, чтобы страны, традиционно занимавшиеся рыболовством в этом районе моря до введения ограничений, могли гарантированно продолжать промысел, а страны, не способные доказать, что занимались рыболовством в этом районе, не получили бы разрешения на его начало. Целью - а также реальным следствием этой меры является защита традиционной отрасли, а не дискриминация лиц, занятых в этой отрасли, по той причине, что они являются или не являются - гражданами той или иной страны. Насколько я понимаю, регулирование, преследующее подобную цель и приводящее к подобным следствиям, и дискриминация по национальному признаку - совершенно разные вещи, и такое регулирование не может противоречить Статьям 2 и 3 Договора о Свальбарде.

\footnotetext{
${ }^{97}$ Решения Верховного суда Норвегии, Norsk Restidende 1996. Р. 624 (неофициальный перевод с норвежского).
}

${ }^{98}$ Ibid. P. 634. 
Право Норвегии вводить дифференцированный подход в соответствии с иными критериями, не связанными с гражданством, в целом признается в литературе, посвященной данному вопросу. Сегодня авторы, занимающиеся этим вопросом, по-прежнему согласны, что Договор не препятствует введению режимов квотирования, подобных действующему в данном случае. Это относится и к авторам, которые, освещая другие правовые вопросы, связанные с суверенитетом Норвегии над Свальбардом, подвергают критике точку зрения Норвегии. Позвольте в этой связи сослаться на работы P.P. Черчилля (R.R. Churchill, "The Maritime Zones of Spitsbergen” («Морские зоны около Шпицбергена»), в книге The Law of the Sea and International Shipping («Морское право и международное судоходство»), 1985. Р. 230231, Note 29) и Гейра Ульфстейна (Geir Ulfstein, The Svalbard Treaty («Договор о Шпицбергене»), 1995. Р. 450 ff.).

Регулирование на основе традиционного рыболовного промысла принято и в международной практике, в случаях, когда с юридической точки зрения отправным пунктом являлся запрет на дискриминацию по национальному признаку. В ряде решений Европейского суда предполагается, что подобное регулирование не противоречит Римскому договору.

Как уже указывалось, апеллянты считают, что Норвегия может установить общую квоту в рыбоохранной зоне, но ни одному государству - и уж, конечно, тем государствам, что присоединились к Договору о Свальбарде, - не может быть запрещен доступ к рыболовным промыслам в этой зоне. Договор открыт для присоединения любой страны. [...] Если бы точка зрения апеллянтов была правильной, то все страны, желающие получить для своих кораблей разрешение заниматься рыболовством в водах вокруг Свальбарда, могли бы добиться этого, присоединившись к договору и потребовав выделения квоты для их рыбаков. Подобная схема была бы практически невозможна и могла бы привести к введению столь малых квот для отдельных третьих стран, что для этих третьих Государств рыболовство на практике превратилось бы в иллюзию»" ${ }^{99}$.

Таким образом, Верховный суд пришел к выводу, что, даже если бы Договор о Шпицбергене и применялся за пределами территориальньх вод, регулирование указанного рыболовства соответствовало бы Договору, поскольку оно не было бы связано с дискриминацией иностранных граждан.

${ }^{99}$ Ibid. P. 635-636. 
На деле принятые меры в основном соблюдались. Указывалось также, что эффективное управление ресурсами в огромной степени связано с легитимностью принимаемых мер ${ }^{100}$. Другой причиной является эффективность мер по управлению ресурсами, принимаемых совместно с Российской Федерацией в отношении всех видов, встречающихся в акватории Баренцева моря, на основе двусторонних соглашений, достигнутых в 1975 и 1976 гг., предусматривавших создание Смешанной комиссии по рыболовству ${ }^{101}$. Другие международные «игроки», например Европейский Союз, де-факто подчинились принятым мерам, хотя и не признают де-юре правовые основания, на которых эти меры строятся.

$$
* * *
$$

В заключение хотелось бы отметить, что в данной статье делается попытка обрисовать ряд элементов, правовых или исторических по своему характеру, которым другие авторы не всегда уделяли внимание. Некоторые данные явно свидетельствуют в пользу строгого толкования сферы применения Договора 1920 г., в соответствии с четкими формулировками, содержащимися в его тексте.

Контекст переговоров, и элементы, проливающие свет на намерения сторон, также служат подтверждению результатов такой интерпретации. В этих целях автор счел полезным обильно процитировать некоторые малоизвестные источники, даже рискуя превысить традиционно принятый объем сносок.

Кроме того, данная интерпретация, судя по всему, больше всего соответствует требованиям нового морского права и критериям совместимости с Конвенцией Монтего Бэй. В конечном итоге политика Норвегии в отношении рыболовства в этом чувствительном регионе диктуется прежде всего заботой о соблюдении существующих с незапамятных времен принципов разумного и устойчивого управления морскими природными ресурсами. Представляется, что этот прагматический, но твердый подход можно признать успешным.

${ }^{100}$ См.: G. Hunneland, "Fisheries in the Svalbard Zone: Legality, Legitimacy and Compliance", в кн. A.G. Oude Elferink and D.R. Rothwell (eds), The Law of the Sea and Polar Maritime Delimitation and Jurisdiction, The Hague, Kluwer Law International, 2001. P. 317-335.

${ }^{101} \mathrm{O}$ сотрудничестве между Норвегией и Российской Федерацией см.: G. Hшnneland, "Enforcement Co-operatiobn between Norway and Russia in the Barents Sea Fisheries", Ocean Development and International Law, Vol. 31, No. 3, 2000. P. 249-268. 